\title{
Challenges and Pitfalls of Experimental Bariatric Procedures in Rats
}

\author{
Lars Fischer $^{\text {a\# }}$ Gabriella Clemens ${ }^{\text {a\# }}$ Tobias Gehrig ${ }^{a}$ Hannes Kenngott ${ }^{a}$ \\ Kristianna Becker $^{b}$ Thomas Bruckner ${ }^{c}$ Carsten N. Gutt ${ }^{a}$ \\ Markus W. Büchler ${ }^{a}$ Beat Müller-Stich ${ }^{a}$ \\ a Department of Surgery, ${ }^{b}$ Interfacultary Biomedical Research Facility (IBF), ${ }^{\text {Institute of }}$ \\ Medical Biometry and Informatics, University of Heidelberg, Heidelberg, Germany
}

\section{Key Words}

Animal models $\cdot$ Bariatric surgery $\cdot$ Surgery

\begin{abstract}
Introduction: The impact of Roux-en-Y gastric bypass (RYGB) and sleeve gastrectomy (SG) on obesity and obesity-related diseases is unquestionable. Up to now, the technical descriptions of these techniques in animals/rats have not been very comprehensive. Methods: For SG and RYGB, operating time, learning curve, and intraoperative mortality in relation to weight of the rat and type of anesthesia were recorded. Furthermore, a review of the literature on experimental approaches towards SG and RYGB in rats was carried out, merging in a detailed technical description for both procedures. Results: The data presented here revealed that the mean operating time for SG $(69.4 \pm 22.2 \mathrm{~min}(\mathrm{SD}))$ was shorter than for RYGB $(123.0 \pm 20.7$ $\mathrm{min})$. There is a learning curve for both procedures, resulting in a reduced operating time of up to $60 \%$ in SG and $35 \%$ in RYGB ( $p<0.05$; t-test). However, with increased weight, operating time increases to about 80 min for SG and about 120 min for RYGB. Obese rats have an increased intraoperative mortality rate of up to $50 \%$. After gaseous anesthesia the mortality can be even higher. The literature search revealed 40 papers dealing with SG and RYGB in rats. 18 articles (45\%) contained neither photographs nor illustrations; 14 articles (35\%) did not mention the applied type of anesthesia. The mortality rate was described in 15 papers (37.5\%). Conclusion: Experimental obesity surgery in rats is challenging. Because of the high mortality in obese rats operated under gaseous anesthesia, exercises to establish the techniques should be performed in small rats using intraperitoneal anesthesia.
\end{abstract}

\#Contributed equally 
Fischer et al.: Challenges and Pitfalls of Experimental Bariatric Procedures in Rats

\section{Introduction}

Obesity and obesity-related diseases are an increasing health care problem within western countries and have become a leading cause of morbidity and mortality [1-3]. Obesity is the main contributory factor to the metabolic syndrome, encompassing dyslipidemia, essential hypertension, insulin resistance, and even insulin-dependent diabetes mellitus [4-6].

The positive impact of surgical interventions such as Roux-en-Y gastric bypass (RYGB) and sleeve gastrectomy (SG) in the management of obesity is unquestioned [1,7-10]. Nowadays, bariatric procedures such as RYGB are used to treat type 2 diabetes mellitus not only in obese patients but also in non-obese insulin-dependent diabetic patients [11-15]. However, the underlying mechanisms responsible for these effects are not well understood [16-19]. This suggests that the number of experimental studies examining these issues will increase over the next few years - particularly as there are rodent models available for studying the effects of bariatric procedures on weight loss and/or the metabolic syndrome [20-24].

Despite well-written descriptions of bariatric procedures in animals presented in previously published literature, surgical details, comprehensive images, technical difficulties, and pitfalls are rarely described [20,23-29]. This makes it difficult to figure out the intricacies of these models. Thus, the aim of this study is to present a detailed surgical description of SG and RYGB in rats, including technical details and advice on how to avoid potential pitfalls.

\section{Material and Methods}

Using PubMed, an online search for surgical techniques used in bariatric procedures in rat models was carried out. As mash terms, the following words were used in different combinations: rat, model, bypass, Roux-en-Y bypass, sleeve, sleeve gastrectomy, bariatric surgery, obesity surgery. After reading the abstracts from 413 articles, 40 papers were thoroughly evaluated. From these 40 articles, methods of anesthesia, sutures/instruments, existence of photos/drawings, mortality rate, and placement of gastrojejunostomy (for RYBG) were extracted. The remaining 373 publications dealt with other procedures such as gastric banding, biliopancreatic diversion, or ileal transposition.

In preparation of an upcoming animal study on diabetic rats, the use of 60 'regular' Sprague Dawley rats (Charles River) was approved by the German Regional Council in order to practice SG and RYGB. For each intervention (SG and RYGB), the weight of the rat, operating time, type of anesthesia, and intraoperative mortality were recorded. In addition, a detailed technical description of each procedure was given. Because of the retrospective nature of this study (surgical procedures, application of narcotic agents, and the weight of the rat were not prospectively planned), statistical analysis was only applied within SG or RYGB. Student's t-test was applied to detect possible differences between groups.

\section{Results}

\section{Literature Review}

From 413 reviewed abstracts, the literature searches eventually uncovered 40 papers dealing with SG or RYGB (10 papers described SG, 30 papers related to RYGB (table 1 and table 2)). All papers were scientifically well written with interesting findings. However, from a technical point of view, the content of most of the papers was unsatisfactory. That is, even though the written technical description was often sufficient, graphical depiction of the surgical procedures was lacking. In 18 papers (45\%) neither photographs nor drawings were 
Table 1. Technical details of sleeve gastrectomy as described in the reviewed literature

\begin{tabular}{|c|c|c|c|c|c|}
\hline Reference & Anesthesia & Sutures & Instruments & $\begin{array}{l}\text { Images } \\
\text { shown }\end{array}$ & Mortality \\
\hline [21] & not described & not described & not described & no & $\mathrm{n} / \mathrm{a}$ \\
\hline$[31]$ & chloral hydrate, i.p. & 8-0, non-absorbable & not described & no & $\mathrm{n} / \mathrm{a}$ \\
\hline [32] & $\begin{array}{l}\text { tiletamine/zolazepam } \\
\text { \& atropine, i.m. }\end{array}$ & 5-0 polypropylene & bulldog forceps & Yes & $\mathrm{n} / \mathrm{a}$ \\
\hline [33] & $\begin{array}{l}\text { sodium pentobarbital, } \\
\text { i.p. }\end{array}$ & 000-gauge thread & $\begin{array}{l}\text { atraumatic hemo- } \\
\text { static forceps }\end{array}$ & Yes & $35 \%$ \\
\hline [25] & $\begin{array}{l}\text { ketamine/xylazine, } \\
\text { i.m. }\end{array}$ & $\begin{array}{l}\text { staple line, } 6-0 \text { poly- } \\
\text { glycolic acid }\end{array}$ & $\begin{array}{l}\text { Stapler TX } 30 \\
\text { B-Ethicon }\end{array}$ & Yes & $0 \%$ \\
\hline$[34]$ & isoflurane & 6-0 prolene & not described & Yes & $0 \%$ \\
\hline$[35]$ & isoflurane & 3-0 Silk & tonsil clamp, scalpel & Yes & $\mathrm{n} / \mathrm{a}$ \\
\hline [36] & chloral hydrate, i.p. & 8-0, non-absorbable & $\begin{array}{l}\text { cauterizer, blade } \\
\text { retracter }\end{array}$ & no & $0 \%$ \\
\hline [36] & chloral hydrate, i.p. & 8-0, non-absorbable & $\begin{array}{l}\text { cauterizer, blade } \\
\text { retracter }\end{array}$ & no & $\mathrm{n} / \mathrm{a}$ \\
\hline [29] & not described & non-absorbable & not described & Yes & $\mathrm{n} / \mathrm{a}$ \\
\hline
\end{tabular}

shown. Based on our subjective assessment, only 5 papers (12.5\%) contained sufficient images of the surgical techniques. Concerning the use of narcotic agents, intramuscular injection, intraperitoneal (i.p.) application, and gaseous anesthesia were used. 14 articles (35\%) did not mention the method of applied anesthesia. The mortality rate was described in 15 papers (37.5\%). In these 15 papers, the mortality rate ranged from $0 \%$ to $42 \%$.

\section{Experimental Data}

\section{Preparation of Animals}

All animals had free access to tap water (also during fasting time) and were fed standard rat food pellets. Rats undergoing surgery were fasted for at least $12 \mathrm{~h}$ before surgery. Initially, it was strongly recommended by our animal facility to fast rats just for about $6 \mathrm{~h}$ before surgery. However, with only $6 \mathrm{~h}$ of fasting, rats still had a lot of food within the stomach, which had to be removed at the beginning of the surgical intervention. Subsequently, contamination of the surrounding tissue was unavoidable.

\section{Preparation of Operating Field}

Rats were placed on a heat plate, which was adjusted to $38^{\circ} \mathrm{C}$ to prevent heat loss during surgery. A $10-\mathrm{ml}$ injection syringe filled with saline was placed on the plate for warm saline solution supply during the experiment. Aseptic pledges, four adhesive strips and the operating instruments were prepared on a sterile towel. After realizing that special instruments for small animals were not suitable, we changed to regular surgical instruments used in pediatric surgery. To take precautions against bleeding, bipolar cauterization was used. 
Table 2. Technical details of Roux-en-Y gastric bypass as described in reviewed the literature

\begin{tabular}{|c|c|c|c|c|c|c|}
\hline Reference & Anesthesia & Visceral sutures & Instruments & $\begin{array}{l}\text { Images } \\
\text { shown }\end{array}$ & $\begin{array}{l}\text { Placement of } \\
\text { gastrojejunostomy }\end{array}$ & Mortality \\
\hline [24] & ketamine/xylazine, i.p. & $\begin{array}{l}\text { titanum staple line, } \\
\text { 4-0 \& 5-0 polyglactin }\end{array}$ & $\begin{array}{l}\text { Stapler TRH30- } \\
\text { 4.8/Ethicon, } \\
\text { Metzenbaum scissors }\end{array}$ & yes & $\begin{array}{l}\text { end-to-side separate } \\
\text { anastomose }\end{array}$ & $4 \%$ \\
\hline [37] & ketamine/xylazine, i.m. & $\begin{array}{l}\text { titanum staple line, } \\
\text { 4-0 \& 5-0 polyglatcin }\end{array}$ & $\begin{array}{l}\text { Stapler TRH30- } \\
\text { 4.8/Ethicon }\end{array}$ & yes & $\begin{array}{l}\text { end-to-side separate } \\
\text { anastomose }\end{array}$ & $37 \%$ \\
\hline [21] & not described & not described & not described & no & not described & $\mathrm{n} / \mathrm{a}$ \\
\hline [38] & ketamine/xylazine, i.p. & $\begin{array}{l}\text { titanum staple line, } \\
5-0 \text { polyglactin }\end{array}$ & $\begin{array}{l}\text { Stapler TRH30- } \\
\text { 4.8/Ethicon }\end{array}$ & yes & $\begin{array}{l}\text { end-to-side separate } \\
\text { anastomose }\end{array}$ & $\mathrm{n} / \mathrm{a}$ \\
\hline [39] & not described & not described & not described & no & not described & $\mathrm{n} / \mathrm{a}$ \\
\hline [40] & not described & 6-0 silk & not described & yes & $\begin{array}{l}\text { side-to-end separate } \\
\text { anastomose }\end{array}$ & $\mathrm{n} / \mathrm{a}$ \\
\hline$[41]$ & ketamine/xylazine, i.p. & not described & $\begin{array}{l}\text { Stapler ENDOPATH } \\
\text { ELC } 35 \mathrm{~mm}\end{array}$ & yes & $\begin{array}{l}\text { end-to-side separate } \\
\text { anastomose }\end{array}$ & $\mathrm{n} / \mathrm{a}$ \\
\hline [42] & not described & not described & not described & yes & not described & $\mathrm{n} / \mathrm{a}$ \\
\hline [43] & isoflurane & not described & not described & yes & $\begin{array}{l}\text { end-to-side separate } \\
\text { anastomose }\end{array}$ & $8 \%$ \\
\hline$[44]$ & not described & not described & not described & no & not described & $\mathrm{n} / \mathrm{a}$ \\
\hline [45] & ketamine/xylazine, i.p. & $\begin{array}{l}\text { staple line, } \\
6-0 \text { polyglactin }\end{array}$ & $\begin{array}{l}\text { linear cutting Sta- } \\
\text { pler/Endopath } \\
\text { Endoscopic TSB } 35\end{array}$ & no & $\begin{array}{l}\text { end-to-side separate } \\
\text { anastomose }\end{array}$ & $\mathrm{n} / \mathrm{a}$ \\
\hline [46] & isoflurane & 6-0 running suture & not described & yes & $\begin{array}{l}\text { end-to-side separate } \\
\text { anastomose }\end{array}$ & $35 \%$ \\
\hline [47] & not described & not described & not described & no & Not described & $\mathrm{n} / \mathrm{a}$ \\
\hline [48] & $\begin{array}{l}\text { ketamin/atropine/ } \\
\text { diazepam }\end{array}$ & not described & not described & no & not described & $\mathrm{n} / \mathrm{a}$ \\
\hline$[26]$ & ketamine/xylazine, i.p. & $\begin{array}{l}\text { staple line, } 5-0 \text { vicryl } \\
\text { and 5-0 prolene }\end{array}$ & $\begin{array}{l}\text { US surgical Stapler } \\
\text { (US Surg. EndoGIA } \\
60 \times 2.5 \mathrm{~mm} \text { ) }\end{array}$ & yes & not described & $\mathrm{n} / \mathrm{a}$ \\
\hline [49] & ketamine/xylazine, i.p. & not described & not described & no & not described & $\mathrm{n} / \mathrm{a}$ \\
\hline$[50]$ & isoflurane & not described & not described & no & $\begin{array}{l}\text { end-to-side separate } \\
\text { anastomose }\end{array}$ & $42 \%$ \\
\hline$[51]$ & not described & not described & not described & no & not described & $\mathrm{n} / \mathrm{a}$ \\
\hline [22] & isoflurane & $\begin{array}{l}\text { staple line, } \\
\text { 5-0 silk-sutures }\end{array}$ & $\begin{array}{l}\text { GIA Stapler ETS- } \\
\text { Flex/Ethicon }\end{array}$ & no & not described & $\mathrm{n} / \mathrm{a}$ \\
\hline [31] & $\begin{array}{l}\text { tiletamin/zolazepam } \\
\text { \& atropine }\end{array}$ & 5-0 polypropylene & not described & yes & not described & $23 \%$ \\
\hline
\end{tabular}


Table 2 (continued)

\begin{tabular}{|c|c|c|c|c|c|c|}
\hline Reference & Anesthesia & Visceral sutures & Instruments & $\begin{array}{l}\text { Images } \\
\text { shown }\end{array}$ & $\begin{array}{l}\text { Placement of } \\
\text { gastrojejunostomy }\end{array}$ & Mortality \\
\hline [52] & isoflurane & 5-0 silk & $\begin{array}{l}\text { GIA Stapler ETS- } \\
\text { Flex/Ethicon }\end{array}$ & yes & not described & $\mathrm{n} / \mathrm{a}$ \\
\hline [53] & not described & staple line & $\begin{array}{l}\text { Stapler/ Ethicon } \\
\text { Endo-Surgery }\end{array}$ & no & $\begin{array}{l}\text { end-to-side separate } \\
\text { anastomose }\end{array}$ & $\mathrm{n} / \mathrm{a}$ \\
\hline [54] & not described & not described & not described & yes & not described & $20 \%$ \\
\hline [55] & inhalation & not described & not described & yes & not described & $\mathrm{n} / \mathrm{a}$ \\
\hline [29] & not described & not described & not described & yes & not described & $\mathrm{n} / \mathrm{a}$ \\
\hline [56] & not described & not described & not described & yes & not described & $\mathrm{n} / \mathrm{a}$ \\
\hline [57] & ketamine/xylazine, i.p. & 6-0 polypropylene & not described & no & $\begin{array}{l}\text { end-to-side separate } \\
\text { anastomose }\end{array}$ & $0 \%$ \\
\hline [58] & isoflurane & staple line & $\begin{array}{l}\text { Stapler } \\
\text { ATW35/Ethicon }\end{array}$ & no & $\begin{array}{l}\text { end-to-side separate } \\
\text { anastomose }\end{array}$ & $40 \%$ \\
\hline [59] & not described & not described & $\begin{array}{l}\text { linear cutting Sta- } \\
\text { pler/ENDOPATH } \\
\text { Endoscopic TSB } 35\end{array}$ & yes & not described & $22 \%$ \\
\hline$[60]$ & isoflurane & not described & $\begin{array}{l}\text { Cutting Stapler } \\
\text { ATW35; Ethicon } \\
\text { Endo-Surgery Inc. }\end{array}$ & no & not described & $20 \%$ \\
\hline
\end{tabular}

\section{Anesthesia}

Owing to experience, the first animals were anesthetized with an i.p. injection of xylazine $(5 \mathrm{mg} / \mathrm{kg}, 2 \%$ solution) + ketamine $(100 \mathrm{mg} / \mathrm{kg} 10 \%$ solution). However, since animals weighing more than $300 \mathrm{~g}$ are difficult to handle and one of the prerequisites at our animal facility was that two persons had to be present in order to administer i.p. injections in conscious rats, we changed to gaseous anesthesia (initially $5 \%$ isoflurane mixed with $1,000 \mathrm{ml}$ oxygen, for maintenance $3 \%$ isoflurane mixed with $750 \mathrm{ml}$ oxygen). Unfortunately, under gaseous anesthesia there was an intraoperative mortality rate of $100 \%$. Despite being very cautious with the anesthesia, this mortality rate did not drop down. Therefore, we switched to the combination of gaseous anesthesia (5\% isoflurane mixed with 1,000 ml oxygen) followed by an i.p. injection of xylazine ( $5 \mathrm{mg} / \mathrm{kg}, 2 \%$ solution) + ketamine (100 $\mathrm{mg} / \mathrm{kg}, 10 \%$ solution) every $30 \mathrm{~min}$ for maintaining anesthesia. Using this approach, we were able to reduce the mortality rate to $0 \%$ for SG and $25 \%$ for RYGB, even in obese rats weighing more than $400 \mathrm{~g}$. 
Fig. 1. Depiction of the incision line for SG (dashed line) and RYGB (dotted line).

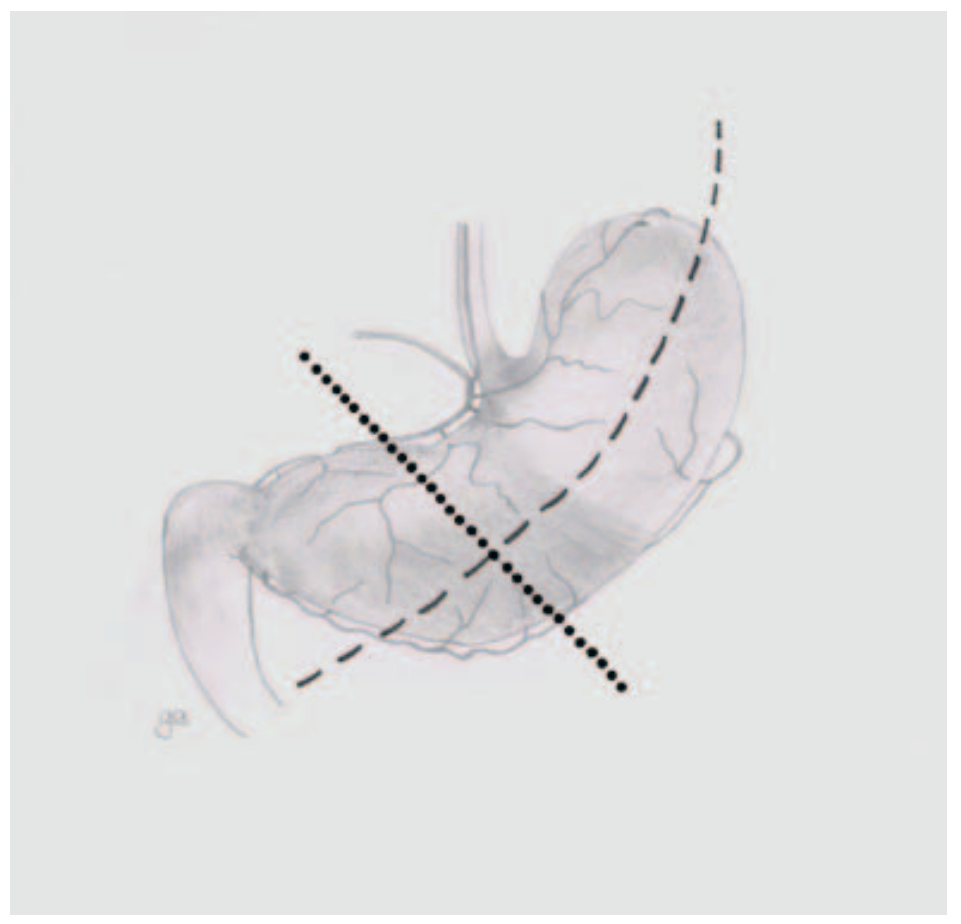

\section{General Setting}

After anesthesia, the lower limbs of the rats were fixed with adhesive strips. The abdomen was shaved and disinfected with alcohol. Starting just below the xiphoid process a 3-cm midline incision was made with straight scissors. In order to keep the abdomen open, one stitch was placed on either side of the incision and fixed by adhesive stripes.

After laparotomy, i.p. antibiotics (metronidazol $1.5 \mathrm{mg} / 100 \mathrm{~g}$, cefotaxime $3 \mathrm{mg} / 100 \mathrm{~g}$ ) were administered. The stomach was identified and carefully exposed. It was important to be very gentle in order to preserve the spleen and pancreas from iatrogenic injuries. To avoid maldigestion, both parts of the stomach (proximal stomach = fore stomach, distal stomach $=$ glandular stomach) needed to be preserved for both SG and RYGB.

During the procedure, $10-20 \mathrm{ml} / \mathrm{kg} / \mathrm{h}$ saline were injected every $30 \mathrm{~min}$ to prevent dehydration. At the end of the procedures, abdominal lavage was performed using $10 \mathrm{ml}$ preheated saline $\left(37^{\circ} \mathrm{C}\right)$. For all anastomosis and intraperitoneal sutures, non-resorbable 5-0 or 6-0 prolene suture (Ethicon, Norderstedt, Germany) with a C-1 needle were used. To ensure open anastomosis and/or detect possible insufficiencies of anastomosis or sutures, saline was injected into the lumen of the respective intestinal structures. In case of suspected insufficiency, this part was closed by a z-suture.

The fascial layer was closed with a non-absorbable running 4-0 vicryl suture (Ethicon). The skin was closed using absorbable interrupted 4-0 prolene suture (Ethicon).

\section{$S G$}

The great omentum was carefully divided along the great curvature of the stomach. In order to empty the stomach from remaining food, a small incision was made at the greater curvature. To ensure the same size of the gastric sleeve, a regular infusion line $(12.1 \mathrm{Ch})$ was shortened and placed inside the stomach along the smaller curvature. The stomach was cut along this infusion tube. The incision line for the SG is shown in figure 1. 
Fig. 2. Final picture of SG. Please pay attention to the single stitches, which prevent mucosa furling and support the running suture as abutment at the same time.

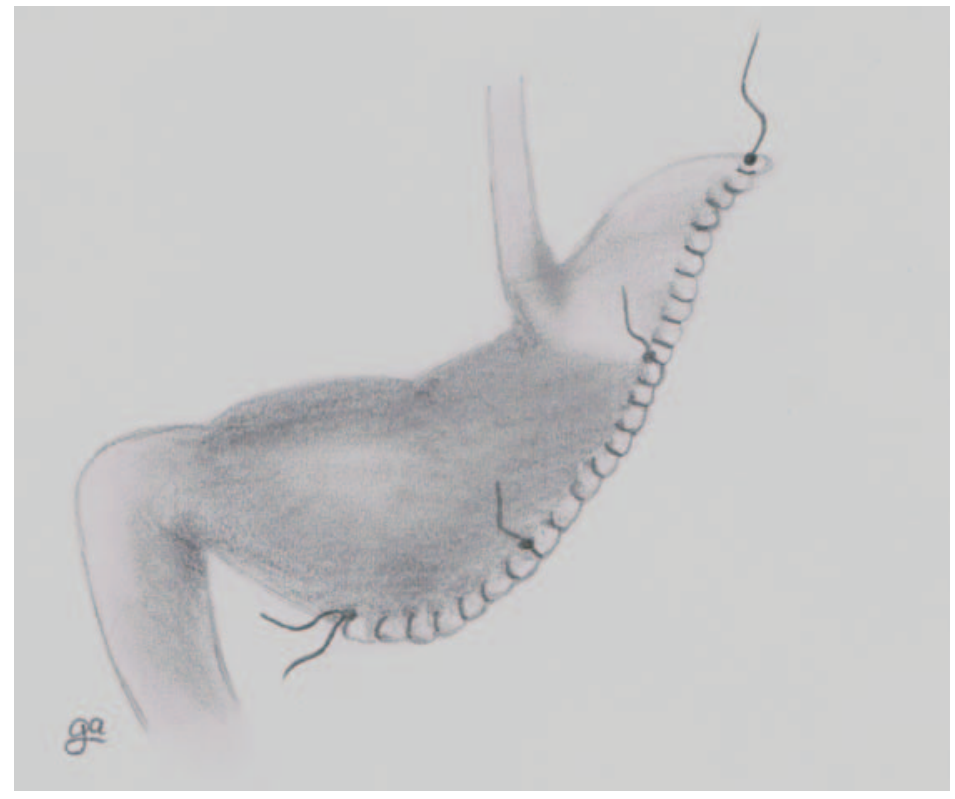

However, it appeared that after cutting the stomach wall, the mucosa furled tremendously, making it very difficult to suture the sleeve adequately. Thus, 2-3 single stitches were place along the resection line (fig. 2). These $2-3$ stitches had two functions. Firstly, they prevented the mucosa from furling, making the final running suture very easy. Secondly, they also functioned as anchor points for the running suture. That is, the free thread ends of each of the single stitches were tied to the running suture that was used to close the stomach in order to form the gastric sleeve.

\section{$R Y G B$}

To empty the stomach, an incision was made at the greater curvature, $1 \mathrm{~cm}$ below the limiting ridge between the fore stomach and glandular stomach. After emptying the stomach, cautery and scissors followed the incision line to the middle of the smaller curvature (as shown in fig. 1).

Meticulous preparation and thorough control of possible bleeding is vital, especially at the smaller curvature. If bleeding occurs, it is generally fatal for the animal. Ligature of the vessels at the smaller curvature was not performed.

The distal part of the stomach was now closed following the same procedure as described for the SG, starting with 2 single stitches to adapt the anterior and posterior walls of the stomach. Then the distal part was closed by a running suture, using the 2 single stitches as anchor points. The proximal part of the stomach was also adapted by 2 stitches and was closed starting by using a running suture at the greater curvature until the first single stitch was reached. After reaching this point, the jejunum was divided $10 \mathrm{~cm}$ distal of the ligament of Treitz. The distal end of the jejunum was pulled up to the stomach, anterior to the colon. To avoid contamination, the opening of the proximal part of the jejunum was placed into a sterile gaze outside the abdomen.

The dorsal wall of the gastrojejunostomy was included in the running suture that closed the proximal part of the stomach (fig. 3a). After finishing the dorsal part of the gastrojejunostomy, the remaining proximal part of the stomach was closed using the single stitch as anchor point. The front wall of the gastrojejunostomy was closed by $4-5$ single stitches (fig. $3 b$ ). 
Fig. 3. a Picture of the RYGB, showing the dorsal wall of the gastrojejunostomy, which is included in the running suture that closes the proximal part of the stomach. The black box reflects the area of the gastrojejunostomy that is shown enlarged in figure 3b. b Magnification of the gastrojejunostomy of the RYGB, showing the single stitches which will be used to close the anterior wall of the anastomosis.

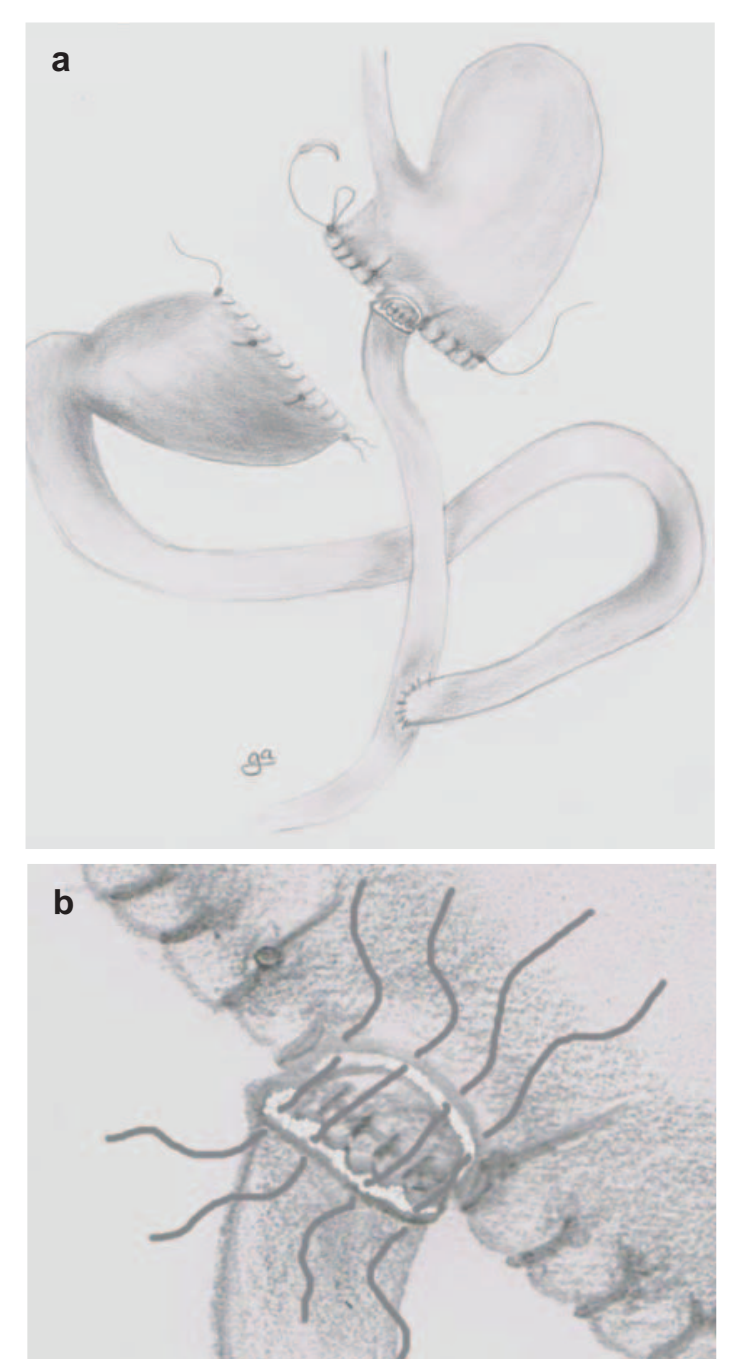

\section{Jejunojejunostomy}

The proximal end of the jejunum needs to be connected end-to-side to the jejunum about $15 \mathrm{~cm}$ distal to the gastrojejunostomy by 2 running sutures. Each of the corners of the anastomosis was approximated with 1 suture. Using these sutures, the dorsal wall was closed; 3 stitches were generally sufficient. Both sutures were knotted (three knots), and the 'other' running suture was used to close the anterior wall of the anastomosis. Again, both sutures were knotted together.

\section{Surgical Results}

The main results are shown in figure 4. In general, SG (69.4 \pm 22.2 min (mean \pm SD)) was performed faster than RYGB $(123.0 \pm 20.7 \mathrm{~min})(\mathrm{p}<0.001)$. There is a learning curve when operating on small animals. The operating time for SG and RYGB improved from Group 1 (SG: $106.7 \pm 15.3 \mathrm{~min}$; RYGB: $150 \pm 3.2 \mathrm{~min})$ to Group 3 (SG: $39.4 \pm 7.5 \mathrm{~min}(\mathrm{p}<0.01)$; RYGB: $101.3 \pm 17.7 \mathrm{~min}(\mathrm{p}<0.05))$. However, the heavier the animal, the longer it took to finish the procedures. Even with expertise, the operating time on obese rats weighing more than $300 \mathrm{~g}$ was about $80 \mathrm{~min}$ for SG and about $120 \mathrm{~min}$ for RYGB. However, comparing operating times of animals using $300 \mathrm{~g}$ as threshold, the differences are not statistically significant ( $\mathrm{p}>0.5$ ). 


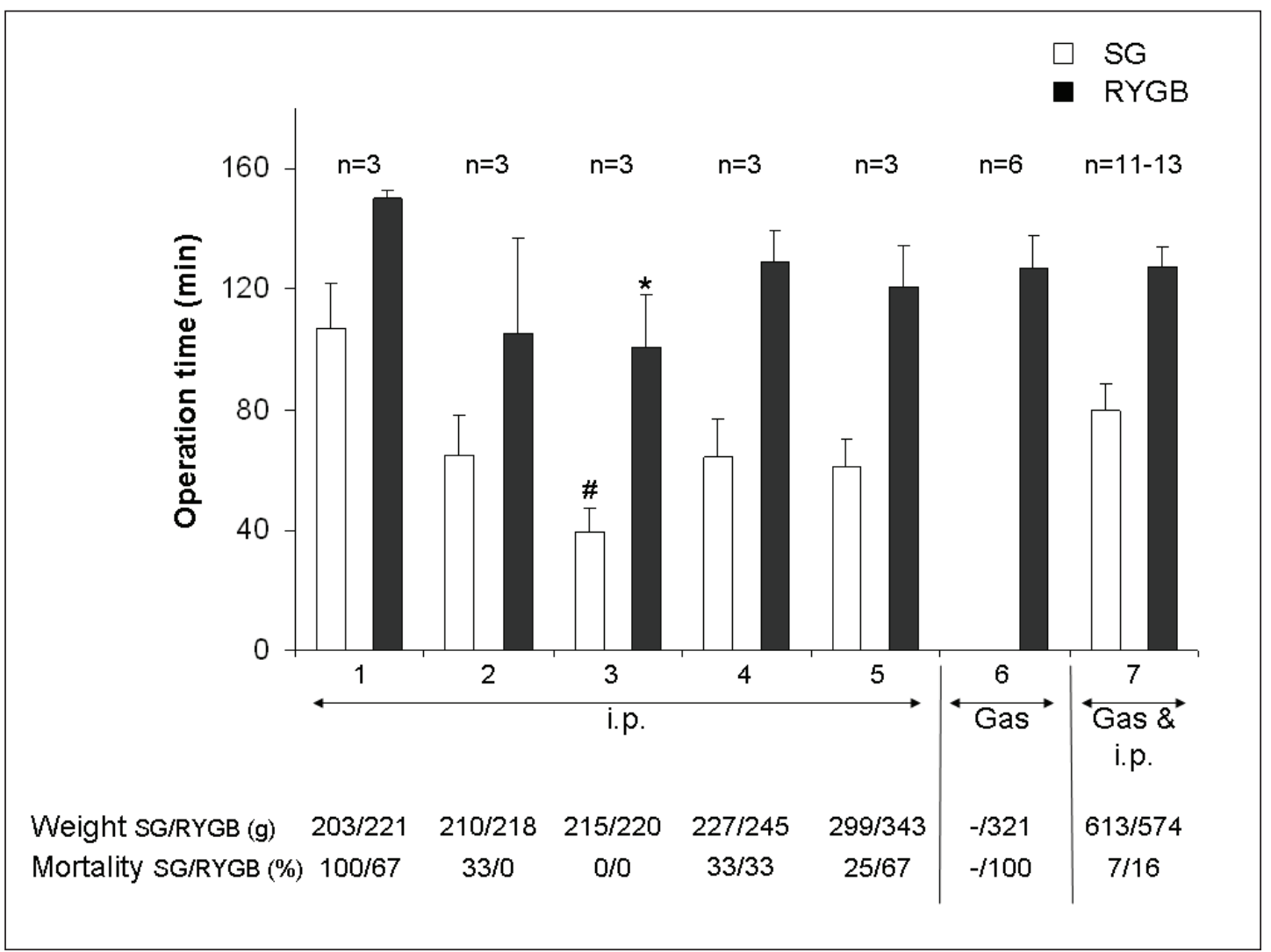

Fig. 4. Graphical depiction showing the impact of animal weight, learning curve, mode of anesthesia on operating time and intraoperative mortality.

Based on our experience, the mortality in these procedures can be quite high. In the beginning, the mortality rate was up to $100 \%$ (Group 1). With more experience, mortality decreased to almost 0\% (Group 3). However, the heavier the animal, the higher the expected mortality. Analysis of all animals (independent of experience and application of narcotics) revealed mortality rates of $30 \%$ in rats weighing up to $300 \mathrm{~g}$ whereas rats weighing more than $300 \mathrm{~g}$ had a mortality rate of $50 \%$ (data not shown). The method of narcotic administration had a tremendous impact on mortality. Using exclusively gaseous anesthesia, all animals died during the surgical procedure, which was not the case with i.p. application. As a consequence, a mixture of gaseous anesthesia and i.p. application was used. However, it is reasonable to suggest that a certain intraoperative mortality rate will remain if using animals weighing over $300 \mathrm{~g}$.

\section{Discussion}

Even though the positive effects of bariatric procedures on weight loss and metabolic syndrome in humans are known, the underlying mechanisms responsible for these effects are not well understood. Thus, it seems reasonable to assume that the number of experimental animal studies analyzing these mechanisms will increase over the next few years. A review of the pertinent literature revealed that the technical descriptions of surgical tech- 
niques are often well written. However, other important details, such as the method of anesthesia, illustrations and mortality rate, are not very detailed, and potential pitfalls are rarely described. This was the main reason for us to present the results of our initial experiences of SG and RYGB in rats.

Based on the data presented here, two main conclusions can be drawn. Firstly, intraoperative mortality and operating time strongly correlates with increasing weight of the animal. Secondly, anesthesia performed purely with gas seemingly increases intraoperative mortality.

One pitfall of this study is the statistical analysis, i.e. only time differences within the two groups (SG, RYGB) but no analysis of differences between SG and RYGB was performed. The main reason for this is that there was no prospective study plan. The results described here often emerged in parallel. For instance, the first operations were SG, performed on about 12 rats weighing less than $300 \mathrm{~g}$. After that RYGB on rats with the same weight was done. However, experiments with SG in more obese rats were started simultaneously. To give another example, we only performed gaseous anesthesia in rats with RYGB. The technique was not tested on rats with SG because of the disastrous RYGB results. This makes it difficult to apply statistics between the groups (operating time, mortality, etc.).

However, the finding that gaseous anesthesia led to an intraoperative mortality rate of $100 \%$ in rats weighing more than $300 \mathrm{~g}$ is of some importance. We do not have a clear explanation for this pattern, but based on previous publications it can be assumed that accumulation of narcotic agents in the fat tissue combined with surgical stress might be responsible [30]. We tried to decrease the mortality rate by different approaches, such as applying as little gas as possible and asking for external support. However, we did not succeed. It may be that in experienced hands, gaseous anesthesia is as good as i.p. anesthesia. However, one recommendation resulting from this study would be that researchers who are not familiar with gaseous anesthesia should use i.p. anesthesia or a combination of gaseous and i.p. anesthesia.

Concerning technical details, some authors suggest placing the gastrojejunostomy on the anterior surface of the gastric wall, similar to humans, creating a complete separate anastomosis. We tested this approach several times. However, it was technically demanding and time-consuming. Thus, we tried to include the gastrojejunostomy into the running suture that closes the proximal part of the stomach. This technique worked quite well. It saved time, and so far there were no insufficient anastomoses. Furthermore, placing single stitches whenever running sutures were applied was also useful. The mucosa of the rat stomach vastly furled after cutting. The single stitches not only prevented this furling but also supported the running suture as abutment, making the anastomosis quite safe.

\section{Conclusion}

Experimental obesity surgery in rats is challenging and needs practice. Initial exercises should be performed on rats weighing less than $300 \mathrm{~g}$, using i.p. anesthesia. However, a certain degree of intraoperative mortality is still to be expected, which should be taken into account when calculating the number of animals required.

\section{Acknowledgements}

This study was supported by the Heidelberg Surgery Foundation. 


\section{Disclosure Statement}

There are no conflict of interests to state.

\section{References}

1 Sjostrom L, Narbro K, Sjostrom CD, Karason K, Larsson B, Wedel H, Lystig T, Sullivan M, Bouchard C, Carlsson B, et al: Effects of bariatric surgery on mortality in Swedish obese subjects. N Engl J Med 2007; 357:741-752.

2 Teucher B, Rohrmann S, Kaaks R: Obesity: focus on all-cause mortality and cancer. Maturitas 2010;65: 112-116.

3 Mehta NK, Chang VW: Mortality attributable to obesity among middle-aged adults in the United States. Demography 2009;46:851-872.

4 Gade W, Gade J: Obesity and metabolic syndrome overview. Clin Lab Sci 2010;23:37-38.

- 5 Healy LA, Ryan AM, Carroll P, Ennis D, Crowley V, Boyle T, Kennedy MJ, Connolly E, Reynolds JV: Metabolic syndrome, central obesity and insulin resistance are associated with adverse pathological features in postmenopausal breast cancer. Clin Oncol (R Coll Radiol) 2010;22:281-288.

- 6 Horwich TB, Fonarow GC: Glucose, obesity, metabolic syndrome, and diabetes relevance to incidence of heart failure. J Am Coll Cardiol 2010;55:283-293.

7 Brethauer SA, Hammel JP, Schauer PR: Systematic review of sleeve gastrectomy as staging and primary bariatric procedure. Surg Obes Relat Dis 2009;5(4):469-475.

$\checkmark 8$ Weiner RA, Weiner S, Pomhoff I, Jacobi C, Makarewicz W, Weigand G: Laparoscopic sleeve gastrectomy influence of sleeve size and resected gastric volume. Obes Surg 2007;17:1297-1305.

9 Stroh C, Birk D, Flade-Kuthe R, Frenken M, Herbig B, Hohne S, Kohler H, Lange V, Ludwig K, Matkowitz R, et al: Results of sleeve gastrectomy-data from a nationwide survey on bariatric surgery in Germany. Obes Surg 2009;19:632-640.

10 Daskalakis M, Weiner RA: Sleeve gastrectomy as a single-stage bariatric operation: indications and limitations. Obes Facts 2009;2(suppl 1):8-10.

11 Buchwald H, Estok R, Fahrbach K, Banel D, Jensen MD, Pories WJ, Bantle JP, Sledge I: Weight and type 2 diabetes after bariatric surgery: systematic review and meta-analysis. Am J Med 2009;122:248-256 e245.

12 Rubino F, Gagner M: Potential of surgery for curing type 2 diabetes mellitus. Ann Surg 2002;236:554-559.

13 Scopinaro N, Papadia F, Marinari G, Camerini G, Adami G: Long-term control of type 2 diabetes mellitus and the other major components of the metabolic syndrome after biliopancreatic diversion in patients with $\mathrm{BMI}<35 \mathrm{~kg} / \mathrm{m}^{2}$. Obes Surg 2007;17:185-192.

14 Dar M, Pories WJ: Bariatric surgery: what is the effect on type 2 diabetes? Curr Opin Investig Drugs 2009; 10:1078-1084.

15 Kim S, Richards WO: Long-term follow-up of the metabolic profiles in obese patients with type 2 diabetes mellitus after Roux-en-Y gastric bypass. Ann Surg 2010;251:1049-1055.

16 Vincent RP, le Roux CW: Changes in gut hormones after bariatric surgery. Clin Endocrinol (Oxf) 2008;69: 173-179.

17 Thaler JP, Cummings DE: Minireview: hormonal and metabolic mechanisms of diabetes remission after gastrointestinal surgery. Endocrinology 2009;150:2518-2525.

-18 Troy S, Soty M, Ribeiro L, Laval L, Migrenne S, Fioramonti X, Pillot B, Fauveau V, Aubert R, Viollet B, et al: Intestinal gluconeogenesis is a key factor for early metabolic changes after gastric bypass but not after gastric lap-band in mice. Cell Metab 2008;8:201-211.

-19 Kokkinos A, le Roux CW, Alexiadou K, Tentolouris N, Vincent RP, Kyriaki D, Perrea D, Ghatei MA, Bloom SR, Katsilambros N: Eating slowly increases the postprandial response of the anorexigenic gut hormones, peptide YY and glucagon-like peptide-1. J Clin Endocrinol Metab 2010;95:333-337.

20 Gates SC, Provancal SJ, Webb JW, Richardson A: Metabolic profiles of rats of different ages. Exp Gerontol 1984;19:279-288.

21 Del Castillo Dejardin D, Sabench Pereferrer F, Hernandez Gonzalez M, Blanco Blasco S, Abello Sala M: The evolution of experimental surgery in the field of morbid obesity. Obes Surg 2004;14:1263-1272.

22 Meirelles K, Ahmed T, Culnan DM, Lynch CJ, Lang CH, Cooney RN: Mechanisms of glucose homeostasis after Roux-en-Y gastric by pass surgery in the obese, insulin-resistant Zucker rat. Ann Surg 2009;249:277-285.

-23 Mistry SB, Omana JJ, Kini S: Rat models for bariatric surgery and surgery for type 2 diabetes mellitus. Obes Surg 2009;19:655-660.

-24 Xu Y, Ohinata K, Meguid MM, Marx W, Tada T, Chen C, Quinn R, Inui A: Gastric bypass model in the obese rat to study metabolic mechanisms of weight loss. J Surg Res 2002;107:56-63.

25 Patrikakos P, Toutouzas KG, Perrea D, Menenakos E, Pantopoulou A, Thomopoulos T, Papadopoulos S, Bramis JI: A surgical rat model of sleeve gastrectomy with staple technique: long-term weight loss results. Obes Surg 2009;19:1586-1590. 
Tichansky DS, Boughter JD Jr, Harper J, Glatt AR, Madan AK: Gastric bypass surgery in rats produces weight loss modeling after human gastric bypass. Obes Surg 2008;18:1246-1250.

-27 Aguirre V, Stylopoulos N, Grinbaum R, Kaplan LM: An endoluminal sleeve induces substantial weight loss and normalizes glucose homeostasis in rats with diet-induced obesity. Obesity (Silver Spring) 2008;16: $2585-2592$.

28 de Bona Castelan J, Bettiol J, d’Acampora AJ, Castelan JV, de Souza JC, Bressiani V, Giroldi SB: Sleeve gastrectomy model in Wistar rats. Obes Surg 2007;17:957-961.

29 Rao RS, Rao V, Kini S: Animal models in bariatric surgery - a review of the surgical techniques and postsurgical physiology. Obes Surg 2010;20:1293-1305.

-30 Janicki PK, Horn JL, Singh G, Franks WT, Janson VE, Franks JJ: Increased anesthetic requirements for isoflurane, halothane, enflurane and desflurane in obese Zucker rats are associated with insulin-induced stimulation of plasma membrane $\mathrm{Ca}^{2+}$-ATPase. Life Sci 1996;59:PL269-275.

-31 Wang Y, Liu J: Plasma ghrelin modulation in gastric band operation and sleeve gastrectomy. Obes Surg 2009;19:357-362.

-32 Pereferrer FS, Gonzàlez MH, Rovira AF, Blasco SB, Rivas AM, del Castillo Déjardin D: Influence of sleeve gastrectomy on several experimental models of obesity: metabolic and hormonal implications. Obes Surg 2008;18:97-108.

-33 Cai J, Zheng C, Xu L, Chen D, Li X, Wu J, Li J, Yin K, Ke Z: Therapeutic effects of sleeve gastrectomy plus gastric remnant banding on weight reduction and gastric dilatation: an animal study. Obes Surg 2008;18:14111147.

-34 Li F, Zhang G, Liang J, Ding X, Cheng Z, Hu S: Sleeve gastrectomy provides a better control of diabetes by decreasing ghrelin in the diabetic Goto-Kakizaki rats. J Gastrointest Surg. 2009;13:2302-2308.

-35 Lopez PP, Nicholson SE, Burkhardt GE, Johnson RA, Johnson FK: Development of a sleeve gastrectomy weight loss model in obese Zucker rats. J Surg Res 2009;157:243-250.

36 Wang Y, Liu J: Sleeve gastrectomy relieves steatohepatitis in high-fat-diet-induced obese rats. Obes Surg 2009;19:921-925.

-37 Ramos EJ, Xu Y, Romanova I, Middleton F, Chen C, Quinn R, Inui A, Das U, Meguid MM: Is obesity an inflammatory disease? Surgery 2003;134:329-335.

-38 Meguid MM, Ramos EJ, Suzuki S, Xu Y, George ZM, Das UN, Hughes K, Quinn R, Chen C, Marx W, Cunningham PR: A surgical rat model of human Roux-en-Y gastric bypass. J Gastrointest Surg 2004;8:621-630.

-39 Xu Y, Ramos EJ, Middleton F, Romanova I, Quinn R, Chen C, Das U, Inui A, Meguid MM: Gene expression profiles post Roux-en-Y gastric bypass. Surgery 2004;136:246-252.

40 Stylopoulos N, Davis P, Pettit JD, Rattner DW, Kaplan LM: Changes in serum ghrelin predict weight loss after Roux-en-Y gastric bypass in rats. Surg Endosc 2005;19:942-946.

-41 Suzuki S, Ramos EJ, Goncalves CG, Chen C, Meguid MM: Changes in GI hormones and their effect on gastric emptying and transit times after Roux-en-Y gastric bypass in rat model. Surgery 2005;138:283-290.

-42 Guijarro A, Kirchner H, Meguid MM: Catabolic effects of gastric by pass in a diet-induced obese rat model. Curr Opin Clin Nutr Metab Care 2006; 9:423-435.

-43 Stenström B, Furnes MW, Tømmerås K, Syversen U, Zhao CM, Chen D: Mechanism of gastric bypass-induced body weight loss: one-year follow-up after micro-gastric bypass in rats. J Gastrointest Surg 2006;10:13841391.

-44 Guijarro A, Suzuki S, Chen C, Kirchner H, Middleton FA, Nadtochiy S, Brookes PS, Niijima A, Inui A, Meguid MM: Characterization of weight loss and weight regain mechanisms after Roux-en-Y gastric bypass in rats. Am J Physiol Regul Integr Comp Physiol 2007;293:R1474-1489.

-45 Aprahamian CJ, Tekant G, Chen M, Yagmurlu A, Yang YK, Loux T, Harmon CM: A rat model of child hood dietinduced obesity: Roux-en-Y gastric bypass induced changes in metabolic parameters and gastric peptide ghrelin. Pediatr Surg Int 2007;23:653-657.

46 Inoue H, Rubino F, Shimada Y, Lindner V, Inoue M, Riegel P, Marescaux J: Risk of gastric cancer after Rouxen-Y gastric bypass. Arch Surg 2007;142:947-953.

-47 Kirchner H, Guijarro A, Meguid MM: Is a model useful in exploring the catabolic mechanisms of weight loss after gastric bypass in humans? Curr Opin Clin Nutr Metab Care 2007;10:463-474.

48 Pacheco D, de Luis DA, Romero A, González Sagrado M, Conde R, Izaola O, Aller R, Delgado A: The effects of duodenal-jejunal exclusion on hormonal regulation of glucose metabolism in Goto-Kakizaki rats. Am J Surg 2007;194:221-224.

-49 Guijarro A, Osei-Hyiaman D, Harvey-White J, Kunos G, Suzuki S, Nadtochiy S, Brookes PS, Meguid MM: Sustained weight loss after Roux-en-Y gastric bypass is characterized by down regulation of endocannabinoids and mitochondrial function. Ann Surg 2008;247:779-790.

-50 Furnes MW, Tømmerås K, Arum CJ, Zhao CM, Chen D: Gastric bypass surgery causes body weight loss without reducing food intake in rats. Obes Surg 2008;18:415-422.

51 Meguid MM, Glade MJ, Middleton FA: Weight regain after Roux-en-Y: a significant 20\% complication related to PYY. Nutrition 2008;24:832-842.

52 Wolff BS, Meirelles K, Meng Q, Pan M, Cooney RN: Roux-en-Y gastric bypass alters small intestine glutamine transport in the obese Zucker rat. Am J Physiol Gastrointest Liver Physiol 2009;297:G594-601. 
-53 Zheng H, Shin AC, Lenard NR, Townsend RL, Patterson LM, Sigalet DL, Berthoud HR: Meal patterns, satiety, and food choice in a rat model of Roux-en-Y gastric bypass surgery. Am J Physiol Regul Integr Comp Physiol 2009;297(5):R1273-1282.

54 Stearns AT, Balakrishnan A, Tavakkolizadeh A: Impact of Roux-en-Y gastric bypass surgery on rat intestinal glucose transport. Am J Physiol Gastrointest Liver Physiol 2009;297:G9500-9507.

55 Stylopoulos N, Hoppin AG, Kaplan LM: Roux-en-Y gastric bypass enhances energy expenditure and extends lifespan in diet-induced obese rats. Obesity (Silver Spring) 2009;17:1839-1847.

56 Bueter M, Löwenstein C, Olbers T, Wang M, Cluny NL, Bloom SR, Sharkey KA, Lutz TA, le Roux CW: Gastric bypass increases energy expenditure in rats. Gastroenterology 2010;138:1845-1853.

57 Rêgo AC, Araújo-Filho I, Azevedo IM, Jácome DT, Ramalho Rde A, Medeiros AC: Biodistribution of technetium-99m pertechnetate after Roux-en-Y gastric bypass (Capella technique) in rats. Acta Cir Bras 2010; 25:9-12.

58 Shin AC, Zheng H, Townsend RL, Sigalet DL, Berthoud HR: Meal-induced hormone responses in a rat model of Roux-en-Y gastric bypass surgery. Endocrinology 2010;151:1588-1597.

-59 Chelikani PK, Shah IH, Taqi E, Sigalet DL, Koopmans HH: Comparison of the effects of Roux-en-Y gastric bypass and ileal transposition surgeries on food intake, body weight, and circulating peptide YY concentrations in rats. Obes Surg. 2010;20:1281-1288.

60 Shin AC, Zheng H, Pistell PJ, Berthoud HR: Roux-en-Y gastric bypass surgery changes food reward in rats. Int J Obes (Lond) 2011;35:642-651.

61 Pereferrer FS, Mercè Hernàndez Gonzàlez, Santiago Blanco Blasco, Antonio Sánchez Marín, Antonio Mo randeira Rivas, Daniel del Castillo Déjardin: The effects of ileal transposition, gastrojejunal bypass and vertical gastroplasty on the regulation of ingestion in an experimental obesity model associated with diabetes mellitus type 2. Cir Espanol 2009;85:222-228. 